\title{
Effect of Sustained Hyperglycemia on the Release of Insulin from the Isolated Perfused Rat Pancreas
}

\author{
KaTSUHIKo WADA, MAMORU KIMURA, KENJi TAKAHASHI, \\ MAKoTO TOMINAGA AND HIDEO SASAKI \\ Third Department of Internal Medicine, Yamagata University \\ School of Medicine, Yamagata 990-23, Japan
}

\begin{abstract}
The modulation of insulin release from the isolated pancreas using normal rats rendered hyperglycemic by in vivo glucose infusion was studied. In $24 \mathrm{~h}$ and $48 \mathrm{~h}$ hyperglycemic rats, the increase in the amount of insulin released was reduced in response to glucose challenge, but was unchanged in relation to arginine challenge. In $48 \mathrm{~h}$ hyperglycemic rats insulin secretion after glucagon challenge was preserved. It was concluded that hyperglycemia itself makes the pancreatic B-cell selectively insensitive to glucose.
\end{abstract}

Key words: Arginine challenge, Glucagon challenge, Hyperglycemia, Insulin secretion, Glucose toxicity.

(Endocrine Journal 40: 237-244, 1993)

\begin{abstract}
ALTHOUGH glucose is known as the most potent insulin secretagogue, many other substances are also known to be capable of stimulating insulin secretion. However, it has been reported that glucose differs from other insulin-secretagogues in the following way. In experimental animals with a reduced volume of $\mathrm{B}$-cells such as streptozotocininduced diabetic rats $[1,2]$ and partially pancreatectomized rats $[3,4]$, and in non-insulin dependent diabetic patients (NIDDM) [5], the response of $\mathrm{B}$-cells to glucose is reduced, but the response to other insulin-secretagogues is preserved.
\end{abstract}

However, it is not clear whether this difference is due to the reduction in $\mathrm{B}$-cell volume or whether it is induced by the increase in the blood glucose level resulting from insulinopenia. There are various experimental limitations in studying streptozotocin-induced or partially pancreatectomized rats or NIDDM patients, because they have both factors, reduced B-cell mass and hyperglycemia.

Received July 20, 1992

Accepted: February 4, 1993

Correspondence to: Dr. Hideo SASAKI, Third Department of Internal Medicine, Yamagata University School of Medicine, 2-2-2 Iida-Nishi, Yamagata City, Yamagata 990-23, Japan
Recently it was postulated that in NIDDM chronic hyperglycemia itself would induce a blunting of the insulin response to glucose challenge [6]. More recently Leahy et al. [7] reported that the increase in insulin secretion caused by glucose challenge and the modulating effect of glucose on arginineinduced insulin release from the isolated rat pancreas were blunted by chronic hyperglycemia induced by the infusion of a high concentration of glucose. However, the cause of this lowered insulin response, observed only in the case of glucose, has not yet been clarified.

To clarify this in the present study we used normal rats with sustained hyperglycemia produced by the infusion of high concentrations of glucose, and investigated the effects of continuous hyperglycemia on insulin release from the isolated perfused pancreas in response to glucose and nonglucose stimuli.

Materials and Methods

1. Preparation of hyperglycemic rats

Male Wistar rats weighing 200-250 g were 
anesthestized by intraperitoneal injection of $70 \mathrm{mg}$ chloral hydrate per $200 \mathrm{~g}$ body weight, and then an incision was made in the right jugular region to expose the right external jugular vein, and a catheter was inserted. One week after the cannulation a $50 \%$ glucose solution was continuously infused through the catheter for 24 or $48 \mathrm{~h}$ at a rate of $1.2 \mathrm{~m} / \mathrm{h}$ with an automatic infusion pump (Harvard, Mills, Mass, USA) to render the rats hyperglycemic, and the infusion was terminated just before the injection of anesthetic for the pancreas perfusion experiment.

While glucose was being infused through the catheter, the rats were allowed to move freely in the cage, within which a swivel was set up to avoid any unnecessary stress due to confinement. Physiological saline was infused as a control. Water and food intake was not restricted.

\section{Isolated rat pancreas perfusion}

The rat pancreas was dissected by the method of Grodsky et al. [8]. Briefly, after the rats had been anesthetized with $60 \mathrm{mg} / \mathrm{kg}$ pentobarbital injected intraperitoneally, the peritoneal cavity was opened and the pancreas and the duodenum were removed en bloc. The pancreas was perfused with a Krebs-Ringer bicarbonate buffer containing 3\% dextran T-40, $0.2 \%$ bovine albumin and $5 \mathrm{mM}$ glucose during entire period of experiment. It was adjusted to $\mathrm{pH} 7.4$ equilibrated with $95 \% \mathrm{O}_{2}-5 \%$ $\mathrm{CO}_{2}$. The perfusate was made to flow into the celiac artery of the dissected pancreatic specimen and to drain from the portal vein at $36-37^{\circ} \mathrm{C}$, at a flow rate of $2.5 \mathrm{~m} / / \mathrm{min}$. Each test reagent was infused from a side arm at the rate of $0.1 \mathrm{~m} l$ per min. The concentrations of tested drugs were expressed as the final concentration in the perfusate. As test reagents, glucose as Dextrose Anhydrous $^{\circledR}$ (Wako Junyaku), arginine as 1 Arginine Monohydrochloride ${ }^{\circledR}$ (Wako Junyaku), and glucagon as Glucagon $\mathrm{Novo}^{\circledR}$ (Novo Industry $\mathrm{A} / \mathrm{S}$ ) were used. Before starting the experiment, the isolated pancreas was perfused with the basal perfusate for the corresponding experiment ( 5 $\mathrm{mM}$ glucose or $5 \mathrm{mM}$ glucose and $10 \mathrm{mM}$ arginine) for $15 \mathrm{~min}$. Effluent was collected every $1 \mathrm{~min}$ in a chilled test tube containing $10 \mathrm{mg}$ EDTA (Wako Junyaku) and $25 \mathrm{mg}$ benzamizin (Aldrich), and stored frozen at $-20^{\circ} \mathrm{C}$.

\section{Assay}

Insulin was measured by RIA with rat insulin standard (Novo Industry) and a Dinabot Insulin RIA-beads kit (Dinabot, Tokyo), and glucose was measured by the glucose oxidase method in a spectrophotometer (U200 Hitachi Co., Tokyo).

For statistical evaluation, the Student's $t$-test for time pointed analysis compared with the mean of 3 points during basal period (Figs. 1-3) and ANOVA for total change analysis (Figs. 4-6) [9] were used, with the difference considered significant when $P<0.05$.

\section{Results}

\section{Plasma glucose and insulin levels}

The plasma glucose levels of the saline-infused control rats fluctuated slightly from 90 to 144 $\mathrm{mg} / \mathrm{d} l$ during the experiment, averaging $111.2 \pm$ $5.9 \mathrm{mg} / \mathrm{d} l$ (mean \pm SEM).

In the rats subjected to continuous glucose infusion, the blood glucose level was increased to $304.3 \pm 34.1 \mathrm{mg} / \mathrm{d} l$ after $24 \mathrm{~h}$ and to $266.5 \pm 46.3$ $\mathrm{mg} / \mathrm{ml}$ after $48 \mathrm{~h}$.

The plasma insulin level in the control rats was $53.8 \pm 9.3 \mu \mathrm{U} / \mathrm{ml}(\mathrm{n}=5)$ before infusion, $64.1 \pm 17.3$ $\mu \mathrm{U} / \mathrm{m} l$ at $24 \mathrm{~h}(\mathrm{n}=3)$ and $50.0 \pm 10.1 \mu \mathrm{U} / \mathrm{m} l$ at $48 \mathrm{~h}$ $(\mathrm{n}=3)$, and in the glucose-infused rats these figures were $148.9 \pm 49.0 \mu \mathrm{U} / \mathrm{ml}$ at $24 \mathrm{~h}(\mathrm{n}=5)$ and $272.4 \pm 24.4 \mu \mathrm{U} / \mathrm{ml}$ at $48 \mathrm{~h}(\mathrm{n}=5)$.

\section{Glucose challenge}

In order to clarify the effect of sustained hyperglycemia on the release of insulin from the isolated perfused pancreas in response to glucose challenge, $15 \mathrm{mM}$ glucose was administered for 15 min in the control, and $24 \mathrm{~h}$ and $48 \mathrm{~h}$ hyperglycemic' rats (Fig. 1).

When $15 \mathrm{mM}$ glucose was administered to the control rat, the insulin concentration in the effluent was increased from $6.2 \pm 0.9 \mu \mathrm{U} / \mathrm{m} l$ in the basal state to a peak of $83.6 \pm 7.3 \mu \mathrm{U} / \mathrm{ml} 2 \mathrm{~min}$ after the start of the administration of the high concentration of glucose. A significant increase in first and second phase insulin release was seen.

In $24 \mathrm{~h}$ hyperglycemic rats challenged in the same way, the insulin concentration was found to 


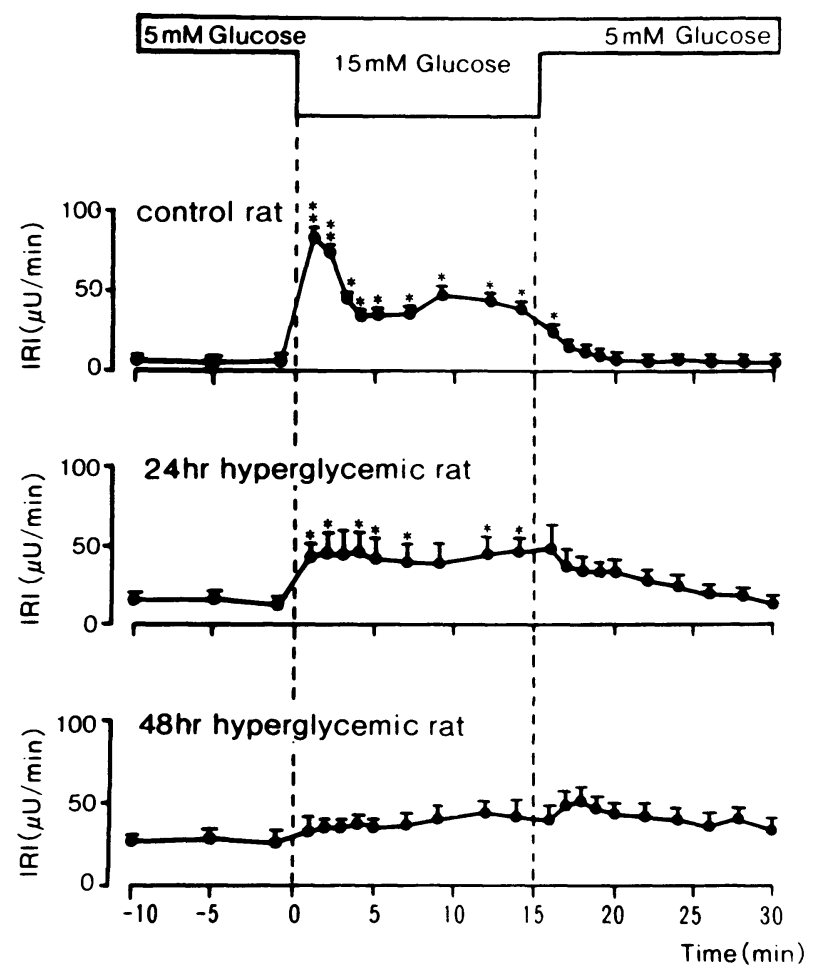

Fig. 1. The modulation of insulin release from the isolated perfused pancreata of the control $(n=5$, upper panel), $24 \mathrm{~h}$ hyperglycemic $(\mathrm{n}=5$, middle panel) and $48 \mathrm{~h}$ hyperglycemic rats $(\mathrm{n}=5$, lower panel) by 15 $\mathrm{mM}$ glucose perfusion. Each point represents the mean \pm SEM. $*$ and $* *$ indicate $P<0.05$ and $P<0.01$, respectively.

be increased to $15.0 \pm 3.9 \mu \mathrm{U} / \mathrm{m} l$ prior to the administration of high concentration of glucose, but the phase 1 peak of $45.9 \pm 17.0 \mu \mathrm{U} / \mathrm{ml} 2 \mathrm{~min}$ after glucose administration was lower than that of the control.

In $48 \mathrm{~h}$ hyperglycemic rats, the insulin concentration in the basal state was $27.7 \pm 6.9 \mu \mathrm{U} / \mathrm{ml}$, a value even higher than those seen in the other 2 groups. However, after $15 \mathrm{mM}$ glucose administration, the first phase peak disappeared and insulin release was only slightly increased. In addition, after the glucose concentration was set back from 15 to $5 \mathrm{mM}$, insulin release tended to gradually increase.

\section{Arginine challenge}

To observe the effect of the sustained hyperglycemic state on insulin release in response to arginine challenge, $20 \mathrm{mM}$ arginine was administered to the control, and 24 and $48 \mathrm{~h}$ hyper-

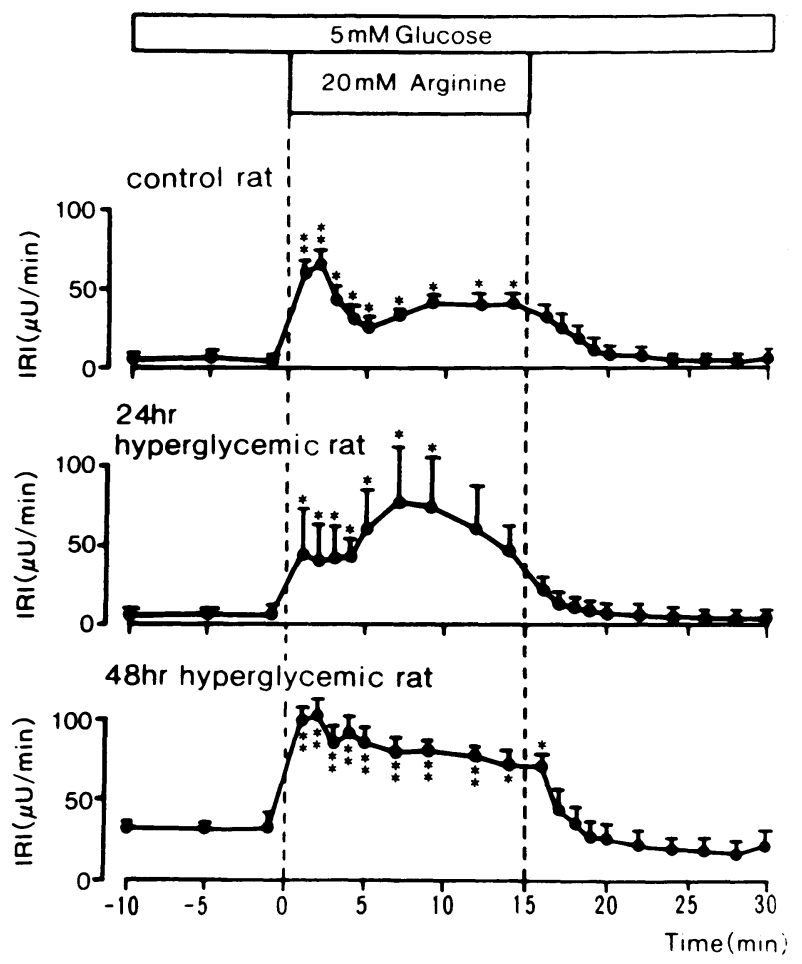

Fig. 2. The modulation of insulin release from the isolated perfused pancreata of the control $(n=5$, upper panel), $24 \mathrm{~h}$ hyperglycemic ( $\mathrm{n}=5$, middle panel) and $48 \mathrm{~h}$ hyperglycemic rats $(n=5$, lower panel) by $20 \mathrm{mM}$ arginine perfusion. Each point represents the mean \pm SEM. * and $* *$ indicate $P<0.05$ and $P<0.01$, respectively.

glycemic rats (Fig. 2).

When $20 \mathrm{mM}$ arginine was administered to the control rats, the insulin concentration in the effluent increased from $5.3 \pm 0.9 \mu \mathrm{U} / \mathrm{ml}$ to a peak of $65.1 \pm 8.7 \mu \mathrm{U} / \mathrm{ml} 2 \mathrm{~min}$ after arginine administration, with significant increases in insulin release in the first and second phases.

In $24 \mathrm{~h}$ hyperglycemic rats, the insulin concentration was $6.4 \pm 0.4 \mu \mathrm{U} / \mathrm{m} l$ prior to arginine infusion. After arginine infusion, a significant increase in insulin release was observed.

In $48 \mathrm{~h}$ hyperglycemic rats, the insulin concentration prior to arginine administration was increased to $32.2 \pm 2.4 \mu \mathrm{U} / \mathrm{m} l$, with a greater increase in insulin release after arginine administration.

\section{Glucagon challenge}

To ascertain whether the insulin response to glucagon is preserved even when hyperglycemia is sustained, $100 \mathrm{nM}$ glucagon was administered to 
$48 \mathrm{~h}$ hyperglycemic rats for $15 \mathrm{~min}$. Since in the control rats even with glucagon administration under infusion of $5 \mathrm{mM}$ glucose no insulin secretion was seen, the glucagon challenge was performed during $10 \mathrm{mM}$ arginine infusion (Fig. $3)$.

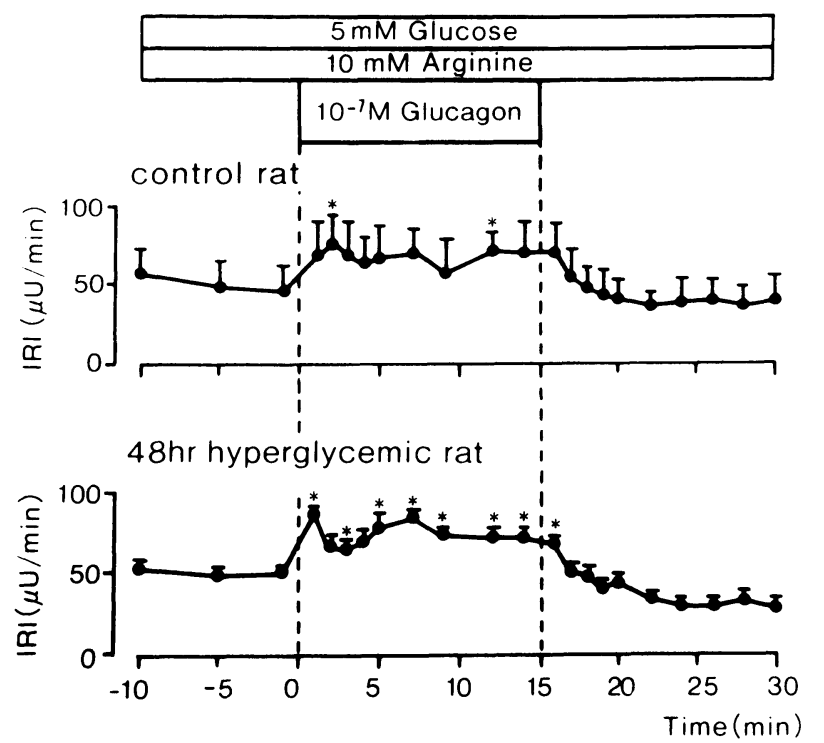

Fig. 3. The modulation of insulin release from the isolated perfused pancreata of the control $(n=5$, upper panel) and $48 \mathrm{~h}$ hyperglycemic rats $(n=5$, lower panel) by $10^{-7} \mathrm{M}$ glucagon perfusion. Each point represents the mean \pm SEM. *indicates $P<0.05$.
The insulin concentration was increased prior to the administration of glucagon at $51.7 \pm 21.0 \mu \mathrm{U} /$ $\mathrm{m} l$ and further increased after glucagon administration in the control rats.

In $48 \mathrm{~h}$ hyperglycemic rats, the insulin concentration was $51.2 \pm 6.8 \mu \mathrm{U} / \mathrm{m} l$ prior to glucagon administration, and a clearer in insulin release was seen after the beginning of glucagon administration.

\section{Average amount of insulin released and amount of} increment in insulin release prior to and during the challenges

In order to quantify the changes in insulin release in response to each challenge, the average amount of insulin released per minute prior to and during the infusion of secretagogues was determined, and the difference between these 2 values was considered to be the actual increase in insulin released.

(1) Glucose challenge

In comparison with the controls, in the 24 and $48 \mathrm{~h}$ groups, the average amount of insulin released was increased prior to challenge. However, the average amount of insulin released during challenge decreased. The increase in insulin released tended to be reduced, showing a significant reduction in the $48 \mathrm{~h}$ group (Fig. 4).

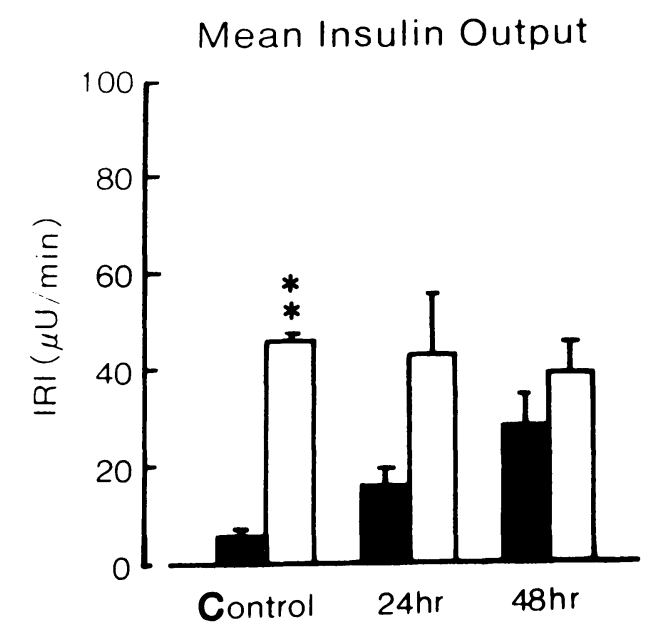

\section{Increase in Insulin Output}

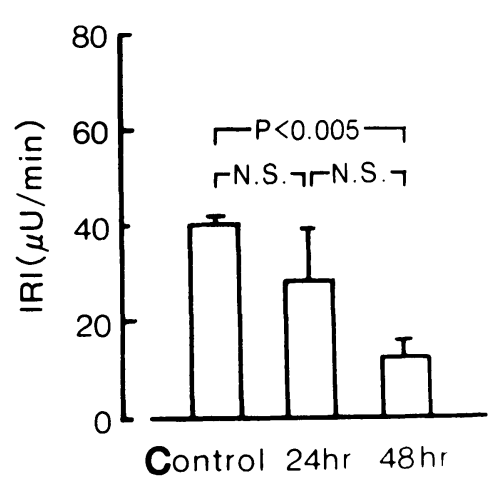

Fig. 4. The mean level of insulin release from the isolated perfused pancreata of the control $(n=5), 24$ h hyperglycemic $(n=5)$ and 48 h hyperglycemic rats $(n=5)$ before (solid bar) and during $15 \mathrm{mM}$ glucose perfusion (open bar) and the net increase in the insulin level in each group (right panel). Each bar represents the mean \pm SEM. ** indicates $P<0.01$. 
Mean Insulin Output

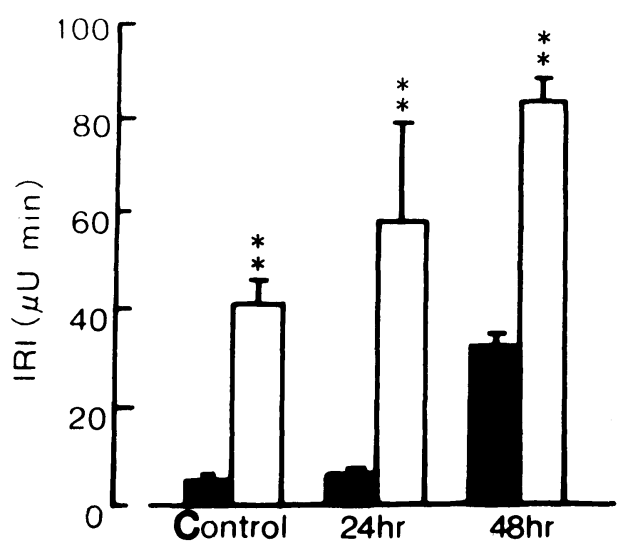

Increase in

Insulin Output

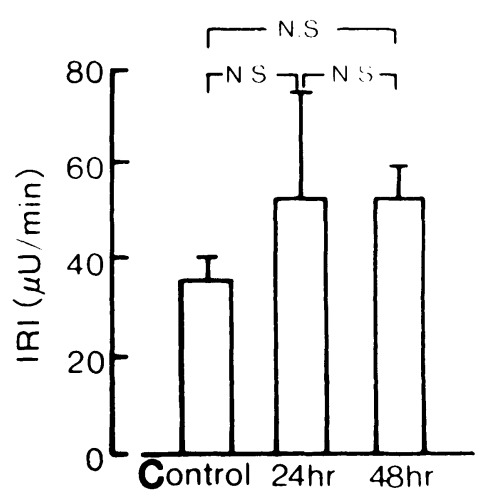

Fig. 5. The mean amount of insulin release from the isolated perfused pancreata of the control $(n=5), 24 h$ hyperglycemic $(n=5)$ and 48 h hyperglycemic rats $(n=5)$ before (open bar) and during $20 \mathrm{mM}$ arginine perfusion (closed bar) and the increase in insulin release in each group (right panel). Each bar represents the mean \pm SEM. ** indicates $P<0.01$.
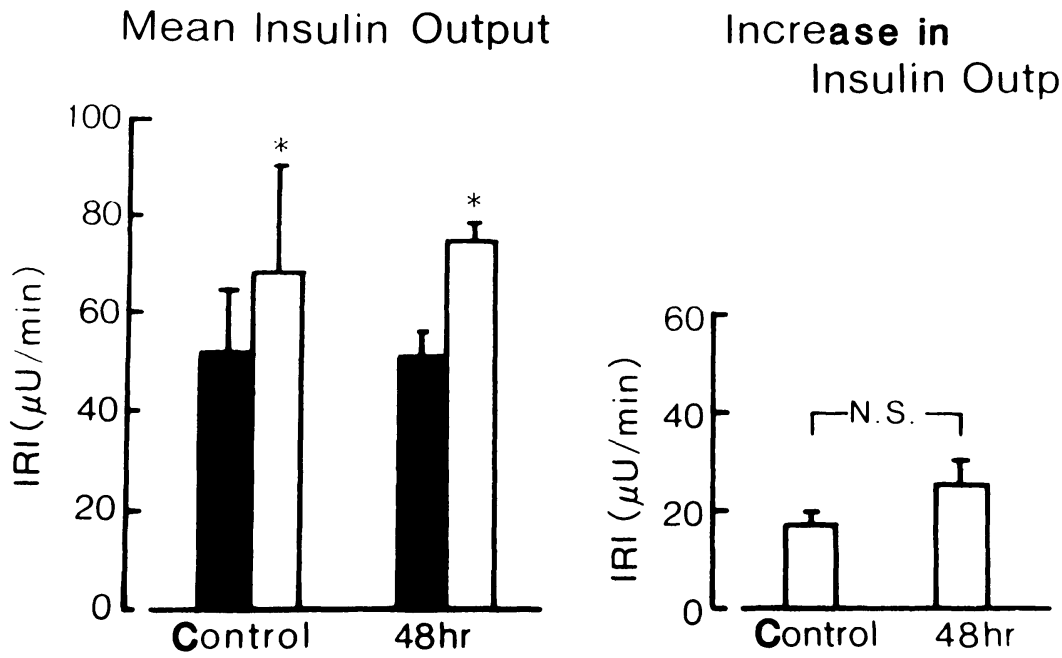

Fig. 6. The mean amount of insulin release from the isolated perfused pancreata of the control $(n=5)$ and 48 hyperglycemic rats $(n=5)$ before (open bar) and during $10^{-7} \mathrm{mM}$ glucagon perfusion (closed bar) and the increase in insulin release in each group (right panel). Each bar represents the mean \pm SEM. * indicates $P<0.05$.

(2) Arginine challenge

In $48 \mathrm{~h}$ hyperglycemic rats, the average amount of insulin released was significantly increased. In addition, the average amount of insulin released during the challenge was also significantly increased. However, there was no significant difference in the increase in the insulin released (Fig. 5).

\section{(3) Glucagon challenge}

In $48 \mathrm{~h}$ hyperglycemic rats, the average amount of insulin released prior to challenge was $48.2 \pm 9.4$ $\mu \mathrm{U} / \mathrm{ml}$, and during challenge was $71.5 \pm 14.5 \mu \mathrm{U} /$ $\mathrm{m} l-$ an increase of $23.9 \pm 5.5 \mu \mathrm{U} / \mathrm{m} l$. No significant difference was found between this value and that obtained from control rats. (Fig. 6). 


\section{Discussion}

In this experiment a decreased insulin response was elucidated only to glucose challenge after sustained hyperglycemia in normal rats, while the insulin response to other challenges was preserved.

Various experimental as well as clinical observations have confirmed that the insulin response to glucose challenge is influenced by a rise in the blood glucose level, in contrast to the preserved insulin response to non-glucose stimuli such as arginine and isoproterenol [1-5].

With regard to NIDDM, Pfeiffer et al. [5] reported that in patients whose fasting blood sugar was above $115 \mathrm{mg} / \mathrm{d} l$, the insulin response to intravenously injected glucose was reduced. However, they also stated that in markedly hyperglycemic patients with a fasting blood glucose of over $200 \mathrm{mg} / \mathrm{d} l$, the insulin response to intravenously injected arginine was also inhibited. It has also been reported that in NIDDM patients the insulin response to intravenous glucose was restored after normalization of the blood glucose level by suitable adjustment of the caloric intake and administration of sulfonylurea or insulin [10-16].

In addition, in rats in the mildly hyperglycemic state resulting from the reduced volume of pancreatic B cells following streptozotocin administration immediately after birth $[1,2]$ or by partial pancreatectomy $[3,4]$, it is noted that deterioration of the insulin response is limited to glucose challenge only. In these experimental systems as well, normalization of the blood glucose level with subcutaneous insulin injections leads to restoration of the insulin response [4].

In the above experimental models, it cannot be concluded that the cause of the diminished insulin response to glucose challenge is only continuous hyperglycemia, because not only is the blood glucose level increased but also the pancreatic $\mathrm{B}$-cell volume is reduced. To overcome this difficulty, it would be better to use a normal animal without a reduced volume of B-cells. Recently, Leahy et al. [7] reported that chronic in vivo glucose infusion into a normal rat resulted in impaired insulin release from the isolated perfused pancreas. In addition, they found that chronic hyperglycemia blunted the enhancing effect of glucose on arginine-induced insulin secretion. However, they did not examine insulin secretion with stimuli other than glucose. In the present study, we produced increased blood glucose levels in normal rats by continuous infusion of a high concentration of glucose, and examined the response not only to glucose but also to arginine and glucagon as non-glucose insulin secretagogues. In this way we showed that hyperglycemia itself was the main factor responsible for the reduced insulin response to glucose challenge.

In $48 \mathrm{~h}$ hyperglycemic rats, when the glucose concentration was set back from $15 \mathrm{mM}$ to $5 \mathrm{mM}$, the insulin level did not decrease, but increased a little. Leahy et al. [7] have also reported this paradoxical increase, but its mechanism remains obscure.

It is not understood why chronic hyperglycemia leads to a blunted insulin response to glucose challenge, nor are the reasons for the reversibility of this change known. As one possibility, it is surmised that the glucose receptors and glucose transporters in the pancreatic B-cells are involved. With prolonged hyperglycemia it is speculated that down regulation of the glucose receptors occurs or that all the glucose transporters become occupied [17, 18, 19]. However, Orci et al. reported that although profound underexpression of GLUT 2 exists in the B cell of Zucker Fatty diabetes rat, GLUT 2 deficiency cannot be induced in normal B cell by in vivo and in vitro exposure to a high concentration of glucose [20,21]. We believe that this is true.

It is also unlikely that metabolic changes during chronic hyperglycemia modulate insulin secretion, because the substances which have an effect on insulin secretion, such as free fatty acids, glucagon and catecholamines, were not increased but rather decreased or unchanged by hyperglycemia in the presence of insulin [22, 23, 24].

As shown in the present study, if prolonged hyperglycemia leads to lowering of pancreatic B-cell function, hyperglycemia would beget even more pronounced hyperglycemia, producing a vicious circle. Unger et al. [6] have emphasized this in their hyperglycemia hypothesis. The clinical importance of this idea is supported by the fact that a very low incidence of overt diabetes mellitus during a 10 year follow-up period was reported in patients with impaired glucose tolerance, who were treated with sulfonylurea [13]. It is also reported that remission is seen in NIDDM patients 
in whom intensive therapy has corrected the blood glucose level [25, 26, 27]. Taken together, com- plete glycemic normalization is important in improving glycemic control of diabetes.

\section{References}

1. Trent DF, Fletcher DJ, May JM, Bonner-Weir S, Weir GC (1984) Abnormal islet and adipocyte function in young B-cell-deficient rats with nearnormoglycemia. Diabetes 33: 170-175.

2. Weir GC, Clore ET, Zmachinski CJ, Bonner-Weir $S$ (1981) Islet secretion in a new experimental model for non-insulin-dependent diabetes. Diabetes 30: 590-595.

3. Bonner-Weir S, Trent DF, Weir GC (1983) Partial pancreatectomy in the rat and subsequent defect in glucose-induced insulin release. J Clin Invest 71 : 1544-1553.

4. Leahy JC, Bonner-Weir S, Weir GC (1984) Abnormal glucose regulation of insulin secretion in models of reduced B-cell mass. Diabetes 30: $667-673$.

5. Pfeiffer MA, Halter JB, Porte D Jr (1981) Insulin secretion in diabetes mellitus. $A m J$ Med 70: 579-587.

6. Unger RH, Grundy S (1985) Hyperglycemia as an inducer as well as a consequence of impaired islet cell function and insulin resistance; implications for the management of diabetes. Diabetologia 28: 119-121.

7. Leahy JL, Cooper HE, Deal DA, Weir GC (1986) Chronic hyperglycemia is associated with impaired glucose influence on insulin secretion-a study in normal rats using in vivo glucose infusion. $\mathrm{J} \mathrm{Clin}$ Invest 77: 908-915.

8. Grodsky GM, Fanska RE (1975) The in vitro perfused pancreas. In: Handman J, O'Mally B, (eds) Methods in Enzymology. Academic Press, New York: 364-372.

9. Snedecor GW, Cochran WC (1967) Statistical Methods. Iowa State Univ. Press, Ames, IAI-593.

10. Hermansen K, Schmitz O, Orskov H (1984) Reversal of $\mathrm{D}$ and $\mathrm{A}$ cell insensitivity to glucose in alloxan diabetic dogs by treatment with the artifical beta cell (Biostator). Diabetes (Suppl 1): 81A.

11. Hidaka H, Nagulesparna M, Klimes I, Clark R, Sasaki H, Aronoff SL, Vasquez B, Rubenstein AH, Unger RH (1982) Improvement of insulin secretion but not insulin resistance after short term control of plasma glucose in obese Type II diabetics. J Clin Endocrinol Metab 54: 217-222.

12. Kosaka K, Kuzuya T, Akanuma Y, Hagura R (1980) Increase in insulin response after treatment of overt maturity-onset diabetes is independent of the mode of treatment. Diabetologia 18: 23-28.

13. Sartor G, Schersten B, Carlstrom S, Melander A, Norden A, Persson G (1980) Ten-year follow-up of subjects with impaired glucose tolerance-prevention of diabetes by tolbutamide and diet regulation. Diabetes 29: 41-49.

14. Savage PJ, Bennion LJ, Flock FV, Nagulesparan M, Roth J, Unger RH, Benett PH (1979) Dietinduced improvement of abnormalities in insulin and glucagon secretion and in insulin receptor binding in diabetes mellitus. J Clin Endocrinol Metab 48: 999-1007.

15. Starke A, McGarry JD, Unger RH (1984) Evidence for direct glucose response by alpha-cells and its attenuation by hyperglycemia. Diabetes 33 (Suppl 1): $80 \mathrm{~A}$.

16. Vague P, Moulin J-P (1982) The defective glucose sensitivity of the $B$ cell in non insulin dependent diabetes. Improvement after twenty hours of normoglycemia. Metabolism 31: 139-142.

17. Gjedde A, Crone C (1981) Blood-brain glucose transfer: repression in chronic hyperglycemia. Science 214: 456-457.

18. Karnieli E, Hissin PJ, Simpson IA, Salans LB (1981) A possible mechanism of insulin resistance in the rat adipose cell in streptozotocin-induced diabetes mellitus. Depletion of intracellular glucose transport system. J Clin Invest 68: 811-814.

19. McCall AI, Millington WR, Wurtman RJ (1982) Metabolic fuel and amino acid transport into the brain in experimental diabetes mellitus. Proc Natl Acad Sci USA 79: 5406-5410.

20. Orci L, Ravvazola M, Baetens D, Inman L, Amherdt M, Peterson RG, Newgard CB, Johnson $\mathrm{JH}$, Unger RH (1990) Evidence that downregulation of $\mathrm{B}$-cell glucose transporters in noninsulin-dependent diabetes may be the cause of diabetic hyperglycemia. Proc Natl Acad Sci USA 87: 9953-9957.

21. Johnson JH, Ogawa A, Chen L, Orci L, Newgard CB, Alam T, Unger RH (1990) Science 250: 546-549.

22. Ohneda A, Aguilar-Parada E, Eisentraut AM, Unger RH (1969) Control of pancreatic glucagon secretion by glucose. Diabetes 18: 1-10.

23. Coleman JF (1980) V. Lipid biosynthesis and catabolism. In: Bondy PK, Rosenberg LE (eds) Metabolic Control and Disease. Saunders Co., Philadelphia: 221-243.

24. Mathias JC, da Costa DF, Fosbraey P, Bannister R, Christensen NJ (1986) Postcibal hypotension in autonomic failure. In: Christensen NJ, Henriksen O, Lassen NA (eds) The Sympatho-Adrenal System. Physiology and Pathology. Munksgaad, 
Copenhagen.

25. Garvey WT, Olefsky JM, Griffin J, Hamman RF, Kolterman OG (1985) The effect of insulin treatment on insulin secretion and insulin action in type II diabetes mellitus. Diabetes 34: 222-234.

26. Andrews WJ, Vasquez B, Nagulesparan M, Klimes I, Foley J, Unger R, Reaven GM (1984) Insulin therapy in obese, non-insulin-dependent diabetes induces improvements in insulin action and secretion that are maintained for two weeks after insulin withdrawal. Diabetes 33: 634-642.

27. Scarlett JA, Gray RS, Griffin J, Olefsky JM, Kolterman OG (1982) Insulin treatment reverses the insulin resistance of type II diabetes mellitus. Diabetes Care 5: 353-363. 